3. Полянський С. В. Агроекологічний стан грунтового покриву еталонних осушувальних систем у басейні р. Прип'ять / Наук. запис. Тернопіл. наи. пед. ун-ту ім. Володимира Гнатюка. Серія: Географія. Тернопіль: СМП «Таір», 2015. №1. Вип. 36. С. 192-200.

4. Полянський С. В. Екологічні проблеми грунтового покриву Волині. Сучасний екологічний стан та перспективи екологічно безпечного стійкого розвитку Волинської областікол: монографія / за ред. В. О. Фесюка. К.: ТОВ «ПІДПРИЄМСТВО «ВІ ЕН ЕЙ», 2016. C. $166-173$

5. Полянський С. В., Власюк О. А., Колошко Л. К. Підхід до використання вироблених і вигорілих торфовищ на території Копаївської осушувальної системи Шацького району / Природа Західного Полісся та прилеглих територій : зб. наук. пр. / відп. ред. Ф. В. Зузук. Луцьк : РВВ «Вежа» Волин. нац. ун-ту ім. Лесі Українки, 2007. № 4. C. $104-105$.

6. Трускавецький Р. С. Торфові грунти і торфовища України. Монографія. Харків: Міськ-друк, 2010. - 278 с.

7. Vasyl O. Fesyuk, Iryna A. Moroz, Larysa T. Chyzhevska, Zoia K. Karpiuk, Serhii V. Polianskyi. Burned peatlands within the Volyn region: state, dynamics, threats, ways of further use. Journ. Geol. Geograph. Geoecology, 29 (3), 2020. P. 483-494. DOI: 10.15421/112043.

DOI https://doi.org/10.30525/978-9934-26-047-6-44

\title{
ВИПАДКИ МАСОВОГО РОЗПОВСЮДЖЕННЯ ВІДКЛАДЕНЬ ПАМОРОЗІ КАТЕГОРІЇ НЯ (НЕБЕЗПЕЧНА) НА ТЕРИТОРІЇ УКРАЇНИ ПРОТЯГОМ 1961-2019 РР. ТА ОГЛЯД СТАНУ ЗБИТКІВ ВІД НИХ
}

\author{
Пясецька С. I. \\ кандидат географічних наук, \\ стариий науковий співробітник \\ Український гідрометеорологічний інститут \\ Державної служби Украӥни з надзвичайних ситуаџій \\ та Національної академії наук України \\ м. Київ, Україна
}

Відкладення паморозі на території України є звичним явищем у продовж місяців холодного періоду року, а також у окремі м'ясці 164 
перехідних сезонів року - наприкінці весни у квітні та у середині осені у жовтні. Серед досліджень щодо виникнення ожеледо-паморозевиїх явищ, а саме паморозі особливо виділяються дослідження Е.П. Драневич, Заморського О.Д., Рудневої О.В. [1, 2, 4] де визначено основні умови іiі утворення, синоптичних ситуацій та просторового поширення. Ними встановлено, що для зернистої паморозі основними передумовами є наявність тривалого туману (щільного серпанку, іноді 3 слабкою мрякою) при температурі близької до $0{ }^{0} \mathrm{C}$ та достатньо високої відносна вологості повітря, а при температурах $-8,-10{ }^{0} \mathrm{C}$ та нижче утворюється здебільшого кристалічна паморозь. Існують випадки коли процес наростання зернистої та кристалічної паморозі може чергуватись. Найнебезпечнішими $є$ відкладення зернистої паморозі, яка подібна до відкладень ожеледі, проте менш щільна. Особливо небезпечними $є$ іiі відкладення якщо їх діаметр становить $\geq 50$ мм, тобто сягають критерію «небезпечних» (НЯ). Такі відкладення $\epsilon$ небезпечними для галузей господарства, які $\epsilon$ залежними від ожеледо-паморозевих явищ - енергетика, електронтанспорт, комунальне та зелене господарство. На тепер існують ряд «Керівництв», «Настанов» та доповнень до них, які регламентують спостереження та опрацювання результатів спостережень за різними видами ожеледо-паморозевих відкладень [3, с. 5צ9]. Зважаючи на триваючу зміну клімату та різкі зміни погодних умов на теперішній час необхідно не тільки проводити моніторинг цих явищ, a й досліджувати умови їх виникнення за сучасних умов та створювати системи адаптації щодо них.

Встановлено, що відкладення паморозі категорії НЯ на території України протягом 1961-1990 рр. спостерігались найбільш часто у січні (92 випадок), лютому (57) та грудні (78). На решту місяців, коли спостерігались такі відкладення припало 78 випадків (20 - березень, 16 - квітень, 6 - жовтень, 36 - листопад). Такі відкладення спостерігались на території 21-ї області - Закарпатті (Плай, Нижні Ворота), Львівщині (Яворів), Чернівеччині (Чернівці), Рівненщині (Дубно, Рівне), Хмельниччині (Шепетівка, Ямпіль), Тернопільщині (Чортків), Івано-Франківщині (Пожежевська, Долина), Вінниччині (Хмільник), Київщині (Миронівка, Яготин, Бориспіль),Чернігівщині (Прилуки), Сумщині (Ромни), Харківщині (Коломак, Богодухів, Касноград), Черкащині (Умань, Жашків), Кіровоградщині (Кропивницький, Долинська, Помічна, Бобринець), Полтавщині (Полтава, Лубни, Гадяч), Одеській (Любашівка), Миколаївщині (Первомайськ), Донеччині (Волноваха), Херсонщині (Нижні Сірогози), Запоріжжі (Пришиб), АР Крим (Ай-Петрі). Не спостерігались такі відкладення на 
Волині, Житомирщині, Луганщині та Дніпропетровщині. По окремих роках цього періоду кількість випадків із відкладеннями паморозі категорії НЯ була різною, проте найбільша кількість таких випадків спостерігалась у 1964 р. і становила 23 випадки. По окремих місяцях найбільша кількість випадків паморозі категорії НЯ ( $\geq 5$ випадків) спостерігалась у січні протягом 1974 -1976 рр., а у грудні - 1970, 1971, 1973, 1977, 1980, 1985, 1986 рр. Протягом 1969-1986 pp. на території України у кожному з років періоду було не менше вищенаведеної кількості, а навіть більше, особливо у 1970, 1973-1975, 1977, 1979, 1980, 1988 коли кількість випадків із відкладеннями паморозі категорії НЯ було від 14 до 18. Найбільш часто вони спостерігались на Закарпатті (Плай, Нижні Ворота), АР Крим (Ай-Петрі), Кіровоградщині (Долинська, Кропивницький, Помічна, Бобринець), Івано-Франківщині (Пожежевська, Долина), Полтавщині (Полтава, Лубни, Гадяч) Хмельниччині, Харківщині (Коломак, Богодухів, Красноград), Київщині (Миронівка, Яготин, Бориспіль) Рівненщині та Черкащині.

Усього протягом 1991-2019 pр. на території України спостерігалось 211 випадків відкладень паморозі категорії НЯ. Найбільш часто вони спостерігались у січні (63), лютому (40) та у грудні (43). На березень, квітень, жовтень та листопад припало 65 випадків (березень - 26, квітень - 6, жовтень - 4 та листопад - 29). На відміну від 1961-1990 pp. вони спостерігались лише у 14 областях, а саме на: Закарпатті (Плай), Чернівеччині (Новодністровськ), Тернопільщині (Тернопіль, Чортків), Івано-Франківщині (Пожежевська), Хмельниччині (Ямпіль, Хмельницький), Київщині (Біла Церква, Баришівка, Чорнобиль), Харківщині (Великий Бурлук), Кіровоградщині (Долинська), Дніпропетровщині (Синельнікове), Донеччині (Дебальцеве), Одещині (Любашівка), Запоріжжі (Пришиб), Миколаївщині (Баштанка) та АР Крим (Ай-Петрі). Не спостерігалось таких випадків відкладень у 11 областях - Львівщині, Чернігівщині, Сумщині, Волині, Рівненщині, Житомирщині, Вінниччині, Полтавщині, Черкащині, Луганщині, Херсонщині. Проте вони 3'явились на Дніпропетровщині. Незмінною виявилась відсутність на Волині, Житомирщині та Луганщині, але постійна наявність їх на Закарпатті (Плай), Хмельниччині (Ямпіль), Тернопільщині (Чортків), Івано-Франківщині (Пожежевська), Одещині (Любашівка), Кіровоградщині (Долинська), Запоріжжі (Пришиб), АР Крим (Ай-Петрі). Дещо змінилась окремі станції в ряді областей на відміну від попереднього періоду - на Київщині такі відкладення спостерігались у Білій Церкві, Баришивці та Чорнобилі, Харківщині - Великий Бурлук, Чернівеччині - Новодністровськ, Миколаївщині - Баштанка. У більшості областей на окремих станціях спостерігалось по 1 випадку 
таких відкладень, за виключенням Плаю та Ай-Петрі, де кількість таких випадків залишається найбільшою - 182 випадки на Плаю, 9 на Ай-Петрі та 3 на Пожежевській. По окремих роках досліджуваного періоду значна кількість таких випадків спостерігалась у 1992, 1993, 2005-2007, 2011, 2015 та 2018 рр.

Для періоду 1961-1990 pp. періодів масового розповсюдження відкладень паморозі категорії НЯ виявилось 10. Здебільшого вони спостерігались у січні, лютому та грудні і лише окремі у листопаді. У 8 випадках, відкладення паморозі категорії НЯ спостерігалось на території 2 областей, здебільшого на Закарпатті (Плай) та у АР Крим (Ай-Петрі) у грудні 1980 та 1986 рр., лютому1981, 1088 рр., січні 1990 р., а також на території Закарпаття (Плай) та Львівщини (Яворів) у лютому1982 р. та Закарпаття (Плай) і Чернівеччини (Чернівці) у листопаді 1982 р.). На території Закарпаття, Кіровоградщини та Херсонщини такі відкладення спостерігались у грудні 1985 р. Найбільш масове відкладення відкладень паморозі категорії НЯ спостерігалось у січні 1964 р., коли такі відкладення спостерігались на території 12 областей на Рівненщині, Хмельниччині, Вінниччині, Одещині, Миколаївщині, Кіровоградщині, Черкащині, Полтавщині, Київщині, Харківщині, Сумщині та Чернігівщині. Причому найбільше таких випадків відбулось на території центру країни на Кіровоградщині та Полтавщині. Протягом 1991-2019 рр. випадків масового відкладення паморозі категорії НЯ було 7. На відміну від 1961-1990 рр. такі випадки спостерігались у не тільки у січні та грудні, а й у березні. Вони не спостерігались у лютому та листопаді. Найбільше таких випадків спостерігалось у січні 1992, 1999, 2000 рр., 2 випадки у березні 2003, 2017 pp. та 1 у грудні 2007 р. У 4 випадках відкладення паморозі категорії НЯ спостерігались на території 2-х областей на Закарпатті (Плай) та у АР Крим (Ай-Петрі), а у 2-х на території Закарпаття (Плай) та Івано-Франківщини (Пожежевська). Найбільш масштабним виявився такий випадок у січні 1999 р. коли відкладення паморозі категорії НЯ спостерігались на території 6 областей: Тернопільщини, Чернівеччини, Одещини, Миколаївщини, Кіровоградщини, Дніпропетровщини.

Встановлено, що протягом 1961-1990 рр. у 24 випадках відкладень паморозі категорії НЯ спостерігались збитки у окремих галузях господарства та ще у 11 спостерігалась передаварійна ситуація. Випадки відкладень паморозі категорії НЯ, із збитками спостерігались у січні 1964, січні 1966, лютому 1968, грудні 1969, грудні 1970, березні 1971, лютому, березні та грудні 1973, січні 1974, березні 1975, грудні 1987 та 1988 pр. Здебільшого збитки у вигляді руйнування об'єктів інфраструктури - обривів дротів ЛЕП та зв'язку, знеструмлення 
споживачів, ушкодження об'єктів зеленого господарства спостерігались на Рівненщині, Сумщині, Харківщині, Полтавщині, Кіровоградщині, Донеччини та АР Крим. Збитки від таких відкладень частіше спостерігались на Полтавщині, Харківщині та особливо у АР Крим. Перед аварійна ситуація на об'єктах господарського комплексу країни протягом цього часу від таких відкладень паморозі спостерігалась переважно у західних та центральних областях держави.

У 1991-2019 рр. збитки від таких відкладень спостерігались лише у 5 випадках. У 3-х 3 них вони були встановлені у січні 1992 та 2000 pp. на Ай-Петрі, коли ними було лісові насадження у Кримському державному лісовому заповіднику та у січні 1999 р. на Одещині в Любашівському районі де на значній території (35 населених пунктів) було виведено з ладу ЛЕП.

\section{Література:}

1. Драневич Е.П. Гололед и изморозь. Условия образования, прогноз и гололедное районирование северо-запада Европейской территории СССР. Л.: Гидрометеоиздат, 1971. 228 с.

2. Заморский А.Д. Атмосферный лед. Иней, гололед, снег и град. М.-Л.: Изд-во Академии наук СССР, 1955. 377 с.

3. Инструкция по подготовке к работе в зимний период и организации снегоборьбы на железных дорогах, в других филиалах и структурных подразделениях ОАО «РЖД», а также его дочерних и зависимых обществах. // Вагоны и вагонное хозяйство. 2014. №3. М.: Изд-во Российские железные дороги. С. 14-22.

4. Руднева А.В. Гололед и обледенение проводов на территории СССР. Л.: Гидрометеоиздат, 1961. 170 с.

5. Руководство по краткосрочным прогнозам погоды. Ч. І. Л.: Гидрометеоиздат. 1986. -701 с.

6. Руководство по краткосрочным прогнозам погоды. Ч. II. Вып.1. Европейская часть СССР и Закавказье. Л.: Гидрометеоиздат. 1987. $298 \mathrm{c}$.

7. Роз'яснення щодо «Настанови 3 метеорологічного прогнозування» від 01.01.2019 р. на заміну КД 52.4.3.01-03. 6 с.

8. Настанова по службі прогнозів та попереджень про небезпечні і стихійні явища погоди. КД 52. 4.3.01-03. Державна гідрометеорологічна служба. Київ, 2003. 30 с.

9. Настанова гідрометеорологічним станціям і постам. Вип. 3. Ч.І. Метеорологічні спостереження на станціях. К.: Державна гідрометеорологічна служба. 2011. - 279 с. 